\title{
Leukocytes to Total Cells Ratio Measurement
}

National Cancer Institute

\section{Source}

National Cancer Institute. Leukocytes to Total Cells Ratio Measurement. NCI Thesaurus.

Code C135451.

The determination of the ratio of leukocytes compared to total cells present in a sample.

The measurement may be expressed as a ratio or percentage. 